\title{
MộT SỐ YẾU TỐ LIÊN QUAN TỚI VIỆC SỬ DUNGG DICCH VỤ CHĂM SÓC SỨC KHOẺ CỦA BÊNNH NHÂN ĐIỂU TRI ARV TẠI PHÒNG KHÁM NGOẠI TRÚ, BỆNH VIỆN ĐA KHOA TỈNH BẮC NINH
}

\section{TÓM TẮT}

Mục tiêu: Nghiên cứu được thực hiện nhằm tìm hiểu một số yếu tố liên quan đến việc sử dụng dịch vụ chăm sóc sức khoẻ của bệnh nhân điều trị ARV tại phòng khám ngoại trú (PKNT), bệnh viện đa khoa tỉnh Bắc Ninh. Phương pháp nghiển cứu: Nghiên cứu mô tả cắt ngang sư dụng phương pháp nghiên cứu định lượng (với 215 bệnh nhân đang điều trị ARV) kết hợp định tính (phỏng vấn sâu 2 cán bộ y tế và 2 cuộc thảo luận nhóm với 17 bệnh nhân đang điều trị ARV) trong thời gian từ tháng $1 / 2018$ đến tháng $6 / 2018$. Kết quả và kết luân: Nghiên cứu phân tích 19 yếu tố liên quan đến việc sử dụng dịch vụ CSSK của bệnh nhân điêu trị $A R V$ và kết quả có 10 yểu tố liên quan có ý nghĩa thống kê, trong đó có một số yếu tố chính sau: Yếu tố tiền đề: Có mối liên quan giữa giới tính $(\mathrm{OR}=1,932, \quad \mathrm{P}<0,05)$ và khu vực sinh sống $(\mathrm{OR}=2,162, \mathrm{p}<0,05)$ của bệnh nhân điều trị ARV bị ốm trong 6 tháng trước điều tra với việc sử dụng dịch vụ CSSK. Yếu tố tăng cường: Có mối liên quan giữa người hố trợ điều trị với việc sử dụng dịch vụ CSSK của bệnh nhân điều trị ARV bị ốm trong 6 tháng trước điều tra. Yếu tố tạo điều kiện: Thái độ CBYT nhiệt tình $(\mathrm{OR}=4,788, p<0,05)$ và chất lượng dịch vụ tốt $(\mathrm{OR}=11,163, \mathrm{p}<0,05)$ của cơ sở cung cấp dịch vụ có ảnh hướng đến việc sử dụng dịch vụ CSSK tại PKNTBVĐK tỉnh Bắc Ninh.

Tư khoá: yếu tố ảnh hưởng, dịch vụ chăm sóc sức khoẻ, bệnh nhân điều trị ARV, Phòng khám ngoại trú, Bắc Ninh

\section{SUMMARY}

SEVERAL INFLUENCING FACTORS TO HEALTH CARE SERVICE UTILIZATION OF PATIENTS ON ARV TREATMENT IN OUTPATIENT CLINIC, BAC NINH GENERAL HOSPITAL

Objective: The study was conducted to find out some factors related to healthcare service utilization of patients on ARV treatment in outpatient clinics, Bac Ninh general hospital. Methods: Cross-sectional descriptive study using quantitative research method (with 215 patients on ARV treatment) combined qualitative research method (in-depth interview with 2 health workers and 2 group discussions with 17 patients on ARV treatment) during the period from January 2018 to June 2018. Results and conclusions: The study analyzed 19 factors related

\footnotetext{
${ }^{1}$ Trường Đại hoc y tế công cộng

${ }^{2}$ Trung tâm Kiểm soát bệnh tật tỉnh Bắc Ninh

Chịu trách nhiệm chính: Nguyễn Quỳnh Anh

Email: nqa@huph.edu.vn

Ngày nhận bài: 18.01.2021

Ngày phản biên khoa học: 18.3.2021

Ngày duyệt bài: 25.3.2021
}

\section{Nguyễn Quỳnh Anh', Dương Thị Xuân²}

to the use of health care services among patients on ARV treatment and the results had 10 related factors that were statistically significant, including a number of factors. (1) Predisposing factors: There was an association between sex $(\mathrm{OR}=1.932, \mathrm{P}<0.05)$ and area of residence $(\mathrm{OR}=2.162, \mathrm{p}<0.05)$ of the patient on ARV treatment in the 6 months prior to the survey with the use of health care services. (2) Reinforcing factors: There is a relationship between the support person and the use of health care services of patients on ARV treatment who were ill in the 6 months prior to the survey. (3) Enabling factors: The enthusiastic health worker attitude $(O R=4,788, p$ $<0.05)$ and the good service quality (OR $=11,163, p$ $<0.05)$ of the service providers have an impact on the utinization of health care services at the outpatient clinic in Bac Ninh general hospital.

Keywords: Health care service utilization, influencing factors, patients on ARV treatment, outpatent clinic, Bac Ninh

\section{I. ĐẶT VẤN ĐỀ}

Liệu pháp điều trị thuốc kháng vi rút (ARV) đã biến đổi sự lây nhiễm HIV từ nhiễm trùng tiến triển, điển hình là tử vong sau một vài năm mắc bênh sang môt căn bênh mãn tính cần điều trị suốt đời. Ngoài đặc thù bị mắc các bệnh liên quan đến AIDS như nhiễm trùng cơ hội, thì người nhiễm HIV cũng có những vấn đề sức khỏe như bao người bình thường khác. Do vậy nhu câu chăm sóc sức khỏe (CSSK) của người nhiễm HIV đang điều trị ARV cũng có những sự thay đổi nhất định, sẽ không còn chỉ đơn thuần là điều trị kháng vi rút mà là những dịch vụ CSSK khác để cải thiện tình trạng sức khỏe.

Tại Việt Nam, điều trị ARV triển khai ở tất cả 63 tỉnh/thành phố với 401 cơ sở điều trị ngoại trú, 565 cơ sở cấp phát thuốc ARV (1). Tại Bắc Ninh, chương trình điều trị ARV cho bệnh nhân HIV/AIDS bắt đầu triển khai từ năm 2007, tính đến thời điểm hiên tai, số bênh nhân đang điều trị ARV có thẻ BHYT 463 trường hợp $(91,6 \%), 42$ bệnh nhân chưa có BHYT (2). Phòng khám ngoại trú điều trị HIV/AIDS được đặt tại khoa truyền nhiễm thuộc Bệnh viện đa khoa tỉnh Bắc Ninh. Thực trạng sử dụng dịch vụ CSSK của bệnh nhân điêu trị $A R V$ đang được quản lý tại Bệnh viện đa khoa tỉnh Bắc Ninh là $86 \%$ bệnh nhân bị ốm trong vòng 6 tháng trước điều tra, có $7,0 \%$ không sử dụng dịch vụ CSSK nào, 33,0\% tự mua thuốc điêu trị, $23,4 \%$ đến bệnh viện đa khoa 
tỉnh, 9,2\% tới bệnh viện chuyên khoa, 7,0\% mời thây lang tới nhà. Đứng trước thực trạng sử dụng dịch vụ CSSK như vậy, chúng tôi tiển hành tìm hiểu sâu hơn về "Một số yếu tố liên quan tới việc sử dung dịch vu chăm sóc sức khỏe của bệnh nhân điều trị ARV tại phòng khám ngoại trú, bênh viện đa khoa tỉnh Băc Ninh năm 2018"

\section{II. ĐỐI TƯƠNG VÀ PHƯƠNG PHÁP NGHIÊN CỨU}

Thiết kế nghiên cứu: Thiết kế nghiên cứu mô tả cắt ngang có phân tích, kết hợp phương pháp định lượng và định tính

Thời gian và địa điểm nghiên cứu: Từ tháng 1/2018 đến tháng 6/2018, tại Phòng khám ngoại trú, BVĐK tỉnh Bắc Ninh

Đối tượng nghiên cứu: Bệnh nhân đang điều trị ARV tại PKNT, BVĐK tỉnh Bắc Ninh (định lượng + định tính), cán bộ trực tiếp điều trị tại PKNT, Phụ trách phòng khám ngoại trú (định tính)

Cỡ mẫu nghiên cứu và phương pháp chọn mẫu

Mẫu định lượng. Áp dụng công thức tính cõ mẫu cho ước lượng tỷ lệ trong quần thể nghiên cứu mô tả, ta có:

$$
n=\frac{Z_{1-a / 2}^{2} p(1-p)}{d^{2}}
$$

Trong đó: n: cỡ mẫu nhỏ nhất phải đạt được, p: Tỷ lệ bệnh nhân đang điều trị ARV sử dụng dịch vụ CSŚK (đến thời điểm hiện tại, do chưa có nghiên cứu nào tương tự ở Việt Nam, nên chưa biết tỷ lệ trước đó, nên ước tính $\mathrm{p}=50 \%), \mathrm{Z}_{1-\mathrm{a} / 2}$ $=1,96$, (Mức ý nghĩa $a=0,05$ ), d: mức sai số chấp nhận được (trong nghiên cứu này lấy $\mathrm{d}=0,07$ )

$\rightarrow$ Theo công thức trên tính được: $n=196$. Làm tròn số liệu và dự phòng $10 \%$ bỏ cuộc cõ̃ mẫu tối thiểu cần cho nghiên cứu là 215 đối tượng, thực tế đã triển khai điều tra 215 đối tượng.

Mẫu định tính: Thực hiện 02 cuộc phỏng vấn sâu với cán bộ y tế đang làm việc tại PKNT và 04 cuộc thảo luận nhóm với 17 bệnh nhân đang điều trị ARV.

\section{Chọn mẫu}

Nghiên cứu định lượng: Chọn mẫu ngẫu nhiên đơn được tiến hành theo bước sau:

- Bước 1: Thu thập danh sách bệnh nhân đến nhận thuốc ARV tại phòng khám ngoại trú trong thời gian nghiên cứu dự kiến khoảng 400 bệnh nhân, cần tìm 215 bệnh nhân.

Bước 2: Xác định khung mẫu là bệnh nhân đến khám, nhận thuốc ARV trong tháng 416 bệnh nhân, xác định khoảng các cõ̃ mẫu $\mathrm{k}=\mathrm{N} / \mathrm{n}=$ $416 / 215=2$. Lấy bệnh nhân đầu tiên là bệnh nhân đến khám, nhận thuốc đầu tiên trong tháng, chọn bệnh nhân tiếp theo bằng cách cộng thêm 2, cho đến khi đủ cõ̃ mẫu

Nghiên cứu định tính: Sau khi điều tra định lượng, chúng tôi đã lựa chọn 09 bệnh nhân có BHYT và 08 bệnh nhân không có BHYT đồng ý tham gia 04 cuộc thảo luận nhóm.

\section{Phương pháp thu thập số liệu}

Nghiên cứu định lượng: Nghiên cứu sử dụng phương pháp phỏng vấn trực tiếp bằng bộ câu hỏi có cấu trúc.

Nghiên cứu định tính: Nghiên cứu định tính sử dụng phương pháp thảo luận nhóm và phỏng vấn sâu theo hướng dần phỏng vấn bán cấu trúc. Các cuộc phỏng vấn sâu, thảo luận nhóm được thực hiện tại phòng họp, khoa truyền nhiễm Bệnh viện đa khoa tỉnh Bắc Ninh. Thời gian mỗi cuộc thảo luận nhóm, phỏng vấn sâu là 45 phút. Quá trình thảo luận nhóm và phỏng vấn được nghiên cứu viên ghi chép lại thông tin và ghi âm.

Biến số nghiên cứu: Nhóm 1 - Thông tin chung về đối tượng nghiên cứu: gồm 18 biến, Nhóm 2 - Một số yếu tố ảnh hưởng đến việc sử dụng dịch vụ CSSK của bệnh nhân điều trị ARV tại PKNT-BVËK tỉnh Bắc Ninh: Gồm 15 biến

Chủ đề nghiên cứu định tính: Yếu tố ảnh hưởng đến việc sử dụng dịch vụ CSSK tại PKNTBVĐK tỉnh của bệnh nhân điều trị ARV: Yếu tố tiền đề, yếu tố tăng cường, yếu tố tao điều kiên

Phương pháp phân tích số liệu: Số liệu định lượng sau khi thu thập, được thu thập bằng phần mềm Epidata 3.1 và phân tích bằng phần mềm SPSS 19.0. Các cuộc phỏng vấn/thảo luận nhóm sau khi thu thập sẽ được gõ̃ băng, mã hóa theo chủ đề, sau đó lựa chọn các đoạn trích dẫn đưa vào kết quả nghiên cứu.

Đao đức nghiên cứu: Nghiên cứu được triển khai sau khi được Hội đồng đạo đức của Trường đại học $Y$ tế công cộng thông qua tại quyết định số 078/2018/YTCC-HD3 ngày 27/02/2018.

\section{KẾT QUẢ NGHIÊN CỨU}

3.1 Thông tin về đối tượng nghiên cứu. Nghiên cứu đã tiến hành điều tra trên 215 đối tượng đang điều trị ARV tại PKNT - BVĐK tỉnh Bắc Ninh, trong đó có $52,1 \%$ nữ giới. Trình độ học vấn của đối tượng nghiên cứu chủ yễu tập trung ở trình độ THCS (42,8\%). Đa số đối tượng tham gia nghiên cứu đều đã lập gia đình $74,4 \%$. Tỷ lệ đối tượng nghiên cứu đang sống cùng vợ/chồng/bạn tình là $73,9 \%$, có $16,7 \%$ sống cùng con và $0,5 \%$ sống một mình.

3.2 Thực trạng sử dụng dịch vu CSSK của bệnh nhân điều trị ARV tại PKNT- bệnh viện đa khoa tỉnh 


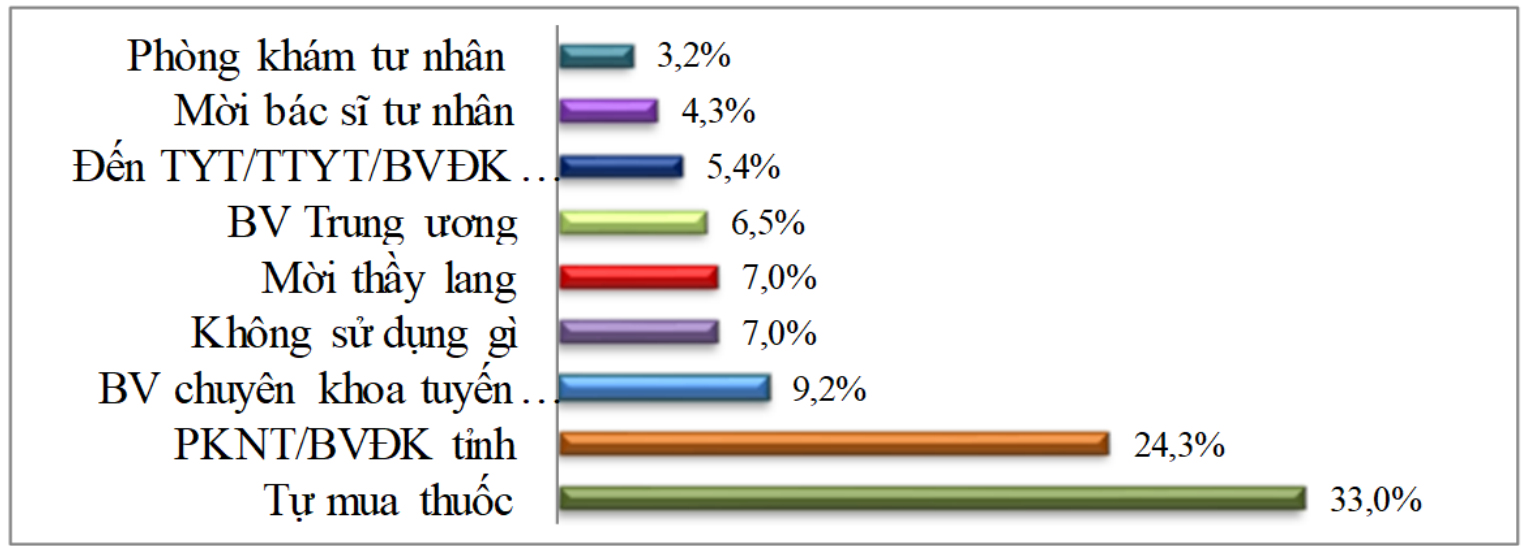

\section{Biểu đồ 3.1. Lựa chọn sử dụng dịch vụ CSSK của bệnh nhân điều trị ARV trong 6 tháng trước điều tra}

Trong số 185 đối tượng nghiên cứu bị ốm trong 6 tháng trước điều tra, người bệnh chủ yếu tự mua thuốc điều trị $(33,0 \%)$ với lý do chủ yếu là bệnh nhẹ $(48,3 \%)$, ngại đi $(43,3 \%)$ và sợ bị kỳ thị $(30,0 \%)$. Lựa chọn tới BVĐK tỉnh nơi có phòng khám ngoại trú để khám và điều trị khá phổ biến chiếm $24,3 \%$. Các lựa chọn mời bác sĩ tư nhân và đến phòng khám/bệnh viện tư nhân chiếm tỷ lệ thấp lần lượt là 4,3\% và 3,2\%.

3.3 Các yếu tố liên quan đến việc sử dụng dịch vụ CSSK của bệnh nhân đang điêuu trị ARV

3.3.1 Yếu tồ tiền đề

Bảng 3.1. Môi liên quan giữa một số đặc điểm nhân khẩu học và sử dụng dịch vụ CSSK của đôîi tượng nghiên cứu

\begin{tabular}{|c|c|c|c|c|c|}
\hline \multirow{2}{*}{ Các yếu tố } & \multicolumn{2}{|c|}{ Sử dụng dịch vụ } & \multirow{2}{*}{ OR (CI 95\%) } & \multirow{2}{*}{$x^{2}$} & \multirow{2}{*}{$\mathbf{p}$} \\
\hline & Có - n (\%) & Không- n(\%) & & & \\
\hline Giới tính: Nữ & $62(63,3)$ & $41(47,1)$ & \multirow{2}{*}{$\begin{array}{c}1,932 \\
(1,073-3,479)\end{array}$} & \multirow{2}{*}{4,864} & \multirow{2}{*}{0.027} \\
\hline $\mathrm{Nam}$ & $36(36,7)$ & $46(52,9)$ & & & \\
\hline Trình độ học vấn: $\leq$ THCS & $54(55,1)$ & $58(66,7)$ & \multirow{2}{*}{$\begin{array}{c}0,614 \\
(0,338-1,115)\end{array}$} & \multirow{2}{*}{2,580} & \multirow{2}{*}{0,108} \\
\hline$>$ THCS & $44(44,9)$ & $37(33,3)$ & & & \\
\hline \multicolumn{6}{|l|}{ Nghề nghiệp hiện tại } \\
\hline Không có việc làm & $8(8,2)$ & $6(6,9)$ & \multirow{2}{*}{$\begin{array}{c}1,200 \\
(0,399-3,606)\end{array}$} & \multirow[b]{2}{*}{0,106} & \multirow[b]{2}{*}{0,745} \\
\hline Có viêc làm & $90(91,8)$ & $81(93,1)$ & & & \\
\hline Tuối: Từ 18-39 tuối & $51(52,0)$ & $41(47,1)$ & \multirow[t]{3}{*}{ 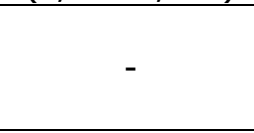 } & \multirow{3}{*}{0,681} & \multirow{3}{*}{0,711} \\
\hline Từ 40-59 tuổi & $45(45,9)$ & $43(49,4)$ & & & \\
\hline Từ 60 tuối trở lên & $2(2,0)$ & $3(3,4)$ & & & \\
\hline \multicolumn{6}{|l|}{ Tình trạng hôn nhân } \\
\hline Chưa lập gia đình & $2(2,0)$ & $2(2,3)$ & \multirow{2}{*}{$\begin{array}{c}0,885 \\
(0,122-6,423)\end{array}$} & \multirow{2}{*}{0,015} & \multirow{2}{*}{0,904} \\
\hline Đã lập gia đình & $96(98,0)$ & $85(97,7)$ & & & \\
\hline \multicolumn{3}{|l|}{ Khu vực sinh sống } & \multirow{3}{*}{$\begin{array}{c}2,162 \\
(1,179-3,965)\end{array}$} & & \\
\hline Thành thị & $47(48,0)$ & $26(29,9)$ & & \multirow{2}{*}{6,302} & \multirow{2}{*}{0,012} \\
\hline Nông thôn & $51(52,0)$ & $61(70,1)$ & & & \\
\hline
\end{tabular}

Tỷ lệ nữ bệnh nhân điều trị ARV sử dụng dịch vụ CSSK $(63,3 \%)$ nhiều hơn nam bệnh nhân 1,932 lần, sự khác biệt này có ý nghĩa thống kê $\left(x^{2}=4,864, p<0,05\right)$. Bệnh nhân điêu trị ARV bị ốm trong vòng 6 tháng trước điều tra ở khu vực thành thị sử dụng dịch vụ CSSK nhiều hơn 2,162 lần bệnh nhân ở khu vực nông thôn, sự khác biệt này có ý nghĩa thống kể $\left(x^{2}=6,302, p<0,05\right)$.

Kết quả nghiên cứu định tính cũng cho thấy, bệnh nhân ở khu vực nông thôn ít có cơ hội tiếp cận với các dịch vụ CSSK hơn bệnh nhân khu vực thành thi:

"Các anh/chị trên thành phố thì dễ, đi khám lúc nào chả được. Bọn em ở quê, có ốm thì uống tạm mây viên thuốc sẵn có trong nhà, chờ đến ngày đi lấy thuốc trên này khám luôn thể, chứ đi khám ở quê họ cũng chả chữa được cho mình" (TLN2, nữ 34 tuổi, có BHYT) 
Bảng 3.2. Môi liên quan giữa bỏ điều trị, bệnh mãn tính với sử dụng dịch vụ CSSK của đôii tượng nghiên cứu

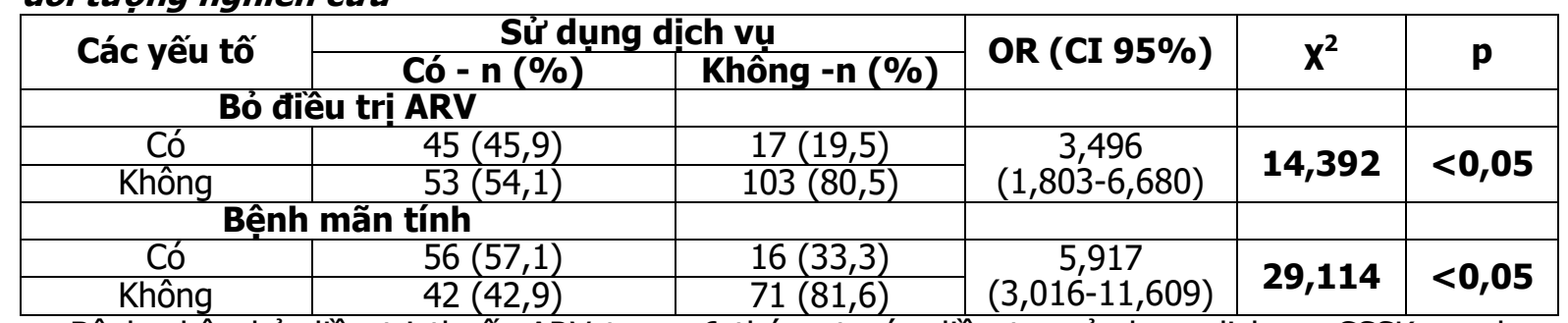

Bênh nhân bỏ điều tri thuốc ARV trong 6 tháng trước điều tra sử dụng dich vu CSSK cao hơn 3,496 lần so với bệnh nhân không bỏ trị. Sự khác biệt này có ý nghĩa thống kê $\left(x^{2}=14,392, p<0,05\right)$. Tương tự, có mối liên quan giữa bệnh mãn tính với sử dụng dịch vụ CSSK của bệnh nhân điều trị ARV $\left(x^{2}=29,114, p<0,05\right)$, những người có kèm theo bệnh mãn tính sử dụng dịch vụ CSSK nhiều hơn 5,917 lần so với người không có bệnh mãn tính.

\subsubsection{Yếu tố tăng cường}

Bảng 3.3. Mối liên quan giứa người hỗ trợ với việc sử dụng dịch vụ CSSK của đôî tượng nghiên cứu

\begin{tabular}{|c|c|c|c|c|c|}
\hline \multirow{2}{*}{ Các yếu tố } & \multicolumn{2}{|c|}{ Sử dụng dịch vụ } & \multirow{2}{*}{ OR (CI 95\%) } & \multirow{2}{*}{$\mathbf{X}^{\mathbf{2}}$} & \multirow{2}{*}{ p } \\
\cline { 2 - 6 } & Có -n (\%) & Không -n (\%) & & \\
\hline Người hố trợ đîêu trị & & & & \\
\hline Có & $71(72,4)$ & $44(50,6)$ & 2,570 & \multirow{2}{*}{$\begin{array}{c}2,375 \\
(1,395-4,733)\end{array}$} & $<0,05$ \\
\hline Không & $27(27,6)$ & $43(49,4)$ & & \\
\hline
\end{tabular}

Có mối liên quan giữa bệnh nhân có người hố trợ điều trị với sử dụng dịch vụ CSSK $(p<0,05)$. Kểt quả cho thấy, bệnh nhân có người hô̂ trợ điêu trị có xu hướng sử dụng dịch vụ CSSK nhiều hơn 2,570 lần bệnh nhân không có người hỗ trợ điều trị. Sự khác biệt có ý nghĩa thống kể $\left(x^{2}=9,375, p<0,05\right)$. Kết quả nghiên cứu định tính cũng cho kết quả tương tự:

"Mình đàn ông, cũng không phải động ốm là đi viện, nhưng vợ mình cứ lo bảo là người bình thường ốm không sao, mình có bất thường về sức khỏe phải đi khám để các bác sĩ điều trị sớm sẽ ổn định hơon" (TLN2, nam 44 tuổi, có BHYT)

Người hỗ trợ điều trị đóng vai trò quan trọng trong chăm sóc sức khỏe người bệnh nói chung và bệnh nhân HIV nói riêng.

"Bệnh nhân có người hỗ trợ điều trị, thường tuân thủ điều trị và đến thăm khám khi bị ốm hoă̆c có vấn đề gì bất thường ngay. Trong trường hợp đó chúng tôi có thể tư vấn và hỗ trợ bệnh nhân điều trị hiệu quả các bệnh kèm theo hơn" (PVS CBYT trực tiếp điều trị)

3.3.3 Yêu tố tạo điều kiện. Chúng tôi không tìm thây mối liên quan giữa điều kiện kinh tế hộ gia đình, khoảng cách đến cơ sở y tế, thẻ BHYT và quy mô gia đình với sử dụng dịch vụ CSSK của bệnh nhân điều trị ARV trong nghiên cứu này ( $p>0,05)$. Không có mối liên quan giữa việc có thẻ hay không có thẻ BHYT của bệnh nhân điêu trị ARV đến sử dụng dịch vụ CSSK $(\mathrm{p}>0,05)$.

Bảng 3.4. Môi liên quan giữa thái độ CBYT, bị kỳ thị, phân biệt đôî xử, chât lượng dịch vụ tốt với sử dụng dịch vụ CSSK của đổi tượng nghiên cứu

\begin{tabular}{|c|c|c|c|c|c|}
\hline \multirow{2}{*}{ Các yếu tố } & \multicolumn{2}{|c|}{ Sử dụng dịch vụ } & \multirow{2}{*}{$\begin{array}{c}\text { OR } \\
\text { (CI 95\%) }\end{array}$} & \multirow{2}{*}{$x^{2}$} & \multirow[b]{2}{*}{ p } \\
\hline & Có-n (\%) & Không-n (\%) & & & \\
\hline Thái độ CBYT nhiệt tình & & & & & \\
\hline Có & $32(32,7)$ & $8(9,2)$ & 4,788 & 14,964 & $<0,05$ \\
\hline \multicolumn{6}{|l|}{ Bi kỳ thi } \\
\hline $\begin{array}{c}\text { Có } \\
\text { Không }\end{array}$ & $\begin{array}{c}8(8,2) \\
90(91,8)\end{array}$ & $\begin{array}{l}13(14,9) \\
74(85,1)\end{array}$ & \multirow[t]{2}{*}{$\begin{array}{c}0,506 \\
(0,199-1,286) \\
\end{array}$} & 2,105 & 0,147 \\
\hline Chất lượng dịc & & & & & \\
\hline $\begin{array}{c}\text { Có } \\
\text { Không }\end{array}$ & $\begin{array}{l}52(53,1) \\
46(46,9)\end{array}$ & $\begin{array}{c}8(9,2) \\
79(90,8)\end{array}$ & $\begin{array}{c}11,163 \\
(4,876-25,56)\end{array}$ & 40,468 & $<0,05$ \\
\hline
\end{tabular}

Không có mối liên quan giữa bị kỳ thị, phân biệt đối xữ với sữ dụng dịch vụ CSSK của đối tượng nghiên cứu $(p>0,05)$. Tuy nhiên, thái độ CBYT nhiệt tình, chất lượng dịch vụ tốt có ảnh hưởng mạnh tới việc sử dụng dụng dịch vụ của đối tượng nghiên cứu $(p<0,05)$. 


\section{BÀN LUÂ̂N}

\subsection{Yếu tố tiền đề (Predisposing factors)} 4.1.1 Đăc điểm nhân khẩu họ:

Giới tính: Kết quả nghiên cứu cho thấy nữ giới nhiễm HIV có xu hướng sử dụng dịch vụ CSSK cao hơn nam giới bị ốm trong 6 tháng trước điều tra. Kết quả này tương đồng với các kết quả nghiên cứu tại Nam Phi (3) và Hoa Kỳ (4).

Tuổi: Tỷ lệ bệnh nhân điều trị ARV bị ốm trong 6 tháng trước điều tra ở nhóm tuổi từ 1839 tuổi sử dụng dich vu CSSK là $55,4 \%$ cao hơn nhóm 40-59 tuổi $(51,1 \%)$ và nhóm từ 60 tuổi trở lên $(40,0 \%)$, tuy nhiên sự khác biêt này không có ý nghĩa thống kê $(p>0,05)$. Kết quả nghiên cứu của Josephs và các cộng sự tuy phân chia nhóm tuổi có hơi khác tuy nhiên cũng cho thấy kết quả tương tự tỷ lệ người nhiễm HIV trong độ tuổi từ 18-49 có xu hướng sử dụng các dịch vư cấp cứu cao hơn so với nhóm trên 50 tuổi, tuy nhiên sự khác biệt này không nhiều (4).

Trình độ học vấn và nghề nghiệp: Kết quả nghiên cứu cho thây trình độ học vấn $(\mathrm{OR}=0,614, \mathrm{p}>0,05)$ và nghề nghiểp của bênh nhân điều trị $A R V$ bị ốm/bệnh $(O R=1,200$, $p>0,05)$ không có mối liên quan đến việc sử dụng dịch vụ CSSK. Trong nghiên cứu của Mosa Moshabela tại khu vực nông thôn và thành thi Nam Phi năm 2012 cũ̃ng không có mối liên quan giữa nghề nghiệp, trình độ học vấn đến sử dụng dịch vụ CSSK $(p>0,05)(5)$.

Tình trạng hôn nhân: Nghiên cứu của chúng tôi không tìm thây mối liên quan có ý nghĩa thống kê giữa tình trạng hôn nhân với việc sử dụng dịch vụ CSSK của bệnh nhân điều trị ARV $(\mathrm{OR}=0,885, \mathrm{p}>0,05)$. Ngược lại với kết quả của nghiên cứu này, nghiên cứu của Fitsum Girma tại Tây Nam Ethiopia năm 2011 chỉ ra có mối liên quan giữa tình trạng hôn nhân với việc sử dụng dịch vụ CSSK tại khu vực y tế công của người ốm/bệnh, người có gia đình sử dụng dịch vụ CSSK gấp 2 lần so với người chưa lập gia đình (6).

\subsubsection{Tình trang bênh tât:}

Bênh mãn tính: Nghiên cứu của chúng tôi cho thấy có mối liên quan giữa tình trạng mắc bệnh mãn tính với việc sử dụng dịch vụ CSSK $(p<0,05)$, bệnh nhân có bệnh mãn tính kèm theo có xu hướng sử dụng dịch vụ CSSK cao hơn 5,917 lần so với bệnh nhân ARV không có bệnh mãn tính. Một số nghiên cứu khác cũng cho thây kết quả tương tự (7), (8).

Yếu tố tăng cường (Reinforcing factors). Sự hỗ trợ của bạn bè, người thân và đồng nghiệp có ảnh hưởng đến việc sử dụng dịch vụ của bệnh nhân điều trị ARV bị ốm trong 6 tháng trước điều tra tại PKNT, cụ thể: Có mối liên quan giữa người hỗ trợ điều trị với việc sử dụng dịch vụ CSSK của ĐTNC $(O R=2,570, p<0,05)$. Nghiên cứu của Beth Rachlis và các cộng sự tại Kenya năm 2012 cho thấy các hỗ trợ từ gia đình, đồng nghiệp và xã hội là yếu tố chính và quan trọng liên kết và duy trì CSSK cho tất cả các loại bệnh của bệnh nhân (9).

Yểu tố tạo điêu kiện (Enabling factors). Thái độ của cán bộ y tế là một trong những yếu tố có ảnh hưởng đến việc sử dụng dịch vụ CSSK của bệnh nhân được nhiều nghiên cứu đề cập, trong nghiên cứu của chúng tồi, thái độ cán bộ y tế nhiệt tình làm tăng tỷ lệ sử dụng dịch vụ CSSK của bệnh nhân điều trị $A R V$ (OR $=4,788$, $\mathrm{p}<0,05)$. Nghiên cứu của Beth Rachlis tại Kenya cũng cho thấy khi được nhân viên y tế quan tâm và tôn trọng bệnh nhân sẽ duy trì tốt việc sử dưng dịch vụ CSSK, tuân thủ theo các hướng dẫn điều trị (9).

\section{KẾT LUÂ̂N}

Nghiên cứu phân tích 19 yếu tố liên quan đến việc sử dụng dịch vụ CSSK của bệnh nhân điều trị $A R V$ và kết quả có 10 yếu tố liên quan có ý nghĩa thống kê, trong đó có một số yếu tố chính sau: Yếu tố tiền đề: Có mối liên quan giữa giới tính $(\mathrm{OR}=1,932, \mathrm{P}<0,05)$ và khu vực sinh sống $(\mathrm{OR}=2,162, \mathrm{p}<0,05)$ của bệnh nhân điều trị ARV bị ốm trong 6 tháng trước điều tra với việc sử dụng dịch vụ CSSK. Yếu tố tăng cường: Có mối liển quan giữa người hỗ trợ điều trị với việc sử dụng dịch vụ CSSK của bệnh nhân điều trị ARV bị ốm trong 6 tháng trước điều tra. Yếu tố tạo điều kiện: Thái độ CBYT nhiệt tình $(\mathrm{OR}=4,788$, $p<0,05)$ và chất lượng dịch vụ tốt $(O R=11,163$, $\mathrm{p}<0,05)$ của cơ sở cung cấp dịch vụ có ảnh hướng đến việc sử dụng dịch vụ CSSK tại PKNTBVĐK tỉnh Bắc Ninh

\section{TÀI LIÊU THAM KHẢO}

1. Bô Y tế (2017), Báo cáo công tác phòng,chông HIIV/AIDS năm 2017 và nhiệm vụ trọng tâm năm 2018, Bộ Y tế, Hà Nội.

2. Trung tâm phòng chống HIV/AIDS Bắc Ninh (2017), Báo cáo hoạt động phòng,chống HIV/AIDS 9 tháng đầu nẳm 2017, phướng hương nhiệm vụ 3 tháng cuối năm 2017, Băc Ninh

3. Hontelez, Jan A. C., et al. (2016), "The Effect of Antiretroviral Treatment on Health Care Utilization in Rural South Africa: A Population-Based Cohort Study", PLOS ONE. 11(7), pg. e0158015.

4. Josephs, J. S., et al. (2010), "Emergency department utilization among HIV-infected patients in a multisite multistate study", HIV Med. 11(1), pg. 74-84.

5. Moshabela, M., et al. (2012), "Factors associated with patterns of plural healthcare 
utilization among patients taking antiretroviral therapy in rural and urban South Africa: a crosssectional study", BMC Health Serv Res. 12, pg. 182

6. Girma, F., Jira, C., and Girma, B. (2011), "Health Services Utilization and Associated Factors in Jimma Zone, South West Ethiopia", Ethiop ] Health Sci. 21(Suppl 1), pg. 85-94

7. Norton, B. L., et al. (2012), "Health Care Utilization in HIV-Infected Patients: Assessing the
Burden of Hepatitis C Virus Coinfection", AIDS Patient Care STDS. 26(9), pg. 541-5

8. Bazie, G. W. (2017), "Modern health services utilization and associated factors in North East Ethiopia". 12(9)

9. Rachlis, Beth, et al. (2016), "Identifying common barriers and facilitators to linkage and retention in chronic disease care in western Kenya", BMC Public Health. 16(1), pg. 741.

\section{ĐÁNH GIÁ KẾT QUẢ SỚM PHẪU THUÂT CẤP CỨU NỐI NGAY MộT THÌ ĐIỀU TRI TẮC RUỘT DO UNG THƯ NỬA TRÁI ĐẠI TRỰC TRÀnG TẠI BỆNH VIỆN $K$}

\section{TÓM TẮT}

Mục tiêu nghiên cứu: Đánh giá kết quả sớm phẫu thuật nối ngay một thì điều trị tắc ruột do ung thư nửa trái đại trực tràng. Đối tượng và phương pháp nghiên cứu: Nghiên cứu mổ tả tiến cứu 42 bệnh nhân phâuu thuật cấp cứu một thìnối ngay điều trị tắc ruột do ung thư nửa trái đại trực tràng từ tháng 1/2018-12/2020 tai bênh viên K. Kết quả: Tuổi trung bình 56,16 $\pm 12,5$ (36-76) tuổi; Nữ 20 (47,6\%), Nam $22(52,4 \%)$. Lý do vào viên đau bung $(100 \%))$; các triệu chứng biểu hiện thường gặp là: đau bụng (100\%), bụng chướng (100\%), bí trung đại tiện $(97,1$ \%), X-quang bụng không chuẩn bị có hình ảnh mức nước hơi (100\%); giải phấu bênh trước mổ $100 \%$ ung thư biểu mô tuyến. CT bụng $100 \%$ chưa có di căn xa.Diện cắt trên trung bình $9,2 \mathrm{~cm}$; diện cắt dưới trung bình $6,4 \mathrm{~cm}$; số lượng hạch vét được trung bình 14,3 hach. Thời gian mồ trung bình 154 phút; thời gian có gas trung bình 4,3 ngày; thời gian hậu phấu 14,1 ngày. Có 2 trường hợp rò $(4,8 \%)$ điêu trị nội khoa ổn định; không có bệnh nhânmổ lại và không có bệnh nhân tử vong. Kết luận: phẫu thuật cấp cứu nối ngay một thì điêu trị tắc ruột do ung thư nửa trái đại trực tràng khả thi và an toàn cả về ngoại khoa và ung thư hoc với nhóm bênh nhân được lựa chon chi tiết

Tư khóa: tắc ruột, ung thư đại trực tràng

\section{SUMMARY}

EARLY RESULTS OF ONE-STAGE ANASTOMOSIS EMERGENCY SURGERY FOR BOWEL OBSTRUCTION DUE TO LEFT COLON CANCER AND UPPER RECTAL CANCER IN K HOSPITAL

\footnotetext{
*Bênh viện $K$

**Đai hoc Y Hà Nôi

Chịu trách nhiệm chính: Phạm Văn Bình

Email: binhva@yahoo.fr

Ngày nhận bài: 20.01.2021

Ngày phản biện khoa học: 18.3.2021

Ngày duyệt bài: 23.3.2021
}

\section{Phạm Văn Bình*, Hoàng Mạnh Thắng**}

Objectives: To evaluate early results of one-stage anastomosis emergency surgery for bowel obstruction due to left colon cancer and upper rectal cancer. Subjects and methods: prospective description with 42 patients was done one-stage anastomosis emergency surgery in treatment of bowel obstruction due to left side colorectal cancer from January 2018 to December 2020 at K hospital. Results: Average age $56.2 \pm 12.5$ (36-76) years; Female $20(47,6 \%)$, Male $22(52,4 \%)$. Reasons for admission to the hospital with abdominal pain (100\%); The most common symptoms were: abdominal pain $(100 \%)$, abdominal swolen $(100 \%)$, inability to pass gas $(97.1 \%)$, abdominal radiograph with air-liquid level (100\%). Preoperative histopathology was $100 \%$ of adenocarcinoma. $100 \%$ abdominal CT did not have distant metastases. Proximal margin on average $10.2 \mathrm{~cm}$; distal marginon average $7.4 \mathrm{~cm}$; the mean harvested lymph nodes was 14.3 . Mean operated time was 154 minutes; average time of gas was 4.3 days; postoperative hospital stay was 14.1 days. There were 2 cases of leakage (4.7\%) with stable medical treatment; No patient was re-operated and no patient died. Conclusion: One-stageanastomosis emergency surgery to treat bowel obstruction due to left side colorectal cancer was feasible and safe both in surgery and oncology with selected patients.

Keywords: Bowel obstruction, colorectal cancer.

\section{I. ĐĂT VẤN ĐỀ}

Ung thư đại trực tràng vẫn là nguyên nhân phổ biến nhất gây tắc ruột ở người lớn và khoảng 20\% bệnh nhân ung thư đại trực tràng đến với cấp cứu ngoại khoa [1],[2]. Với tắc ruột do ung thư đại tràng phải, sự đồng thuận chung trong điều trị là cắt đại tràng phải và nối hồi-đại tràng một thì [4]. Tuy nhiên, phần lớn tắc ruột do ung thư đại trực tràng do u ở nửa trái đại trực tràng và lựa chọn phương pháp điều trị tối ưu cho những trường hợp này còn nhiều tranh luận, đặc biệt đặt trong bối cảnh điêu trị đa mô thức của ung thư đại trực tràng và tỷ lệ biến chứng của phẫu thuật cấp cứu [5]. Chính vì vậy 